ISSN 0258-7122 (Print), 2408-8293 (Online)

Bangladesh J. Agril. Res. 44(3): 525-536, September 2019

\title{
EFFECT OF INTEGRATED NUTRIENT MANAGEMENT ON THE YIELD, YIELD ATTRIBUTES AND PROTEIN CONTENT OF LENTIL
}

\author{
S. AKTAR ${ }^{1}$, M. A. QUDDUS ${ }^{2}$, M. A. HOSSAIN ${ }^{3}$ \\ S. PARVIN ${ }^{4}$ AND M. N. SULTANA ${ }^{5}$
}

\begin{abstract}
A field experiment was conducted at the Pulse Research Sub-station of Bangladesh Agricultural Research Institute (BARI), Gazipur during rabi season of 2015-16 and 2016-17 to evaluate the effectiveness of organic and inorganic sources of nutrients in terms of growth and yield maximization of lentil. The experiment was laid out in a randomized complete block design (RCBD) having six treatments with three replications. The treatments were $\mathrm{T}_{1}=$ Recommended dose $\left(\mathrm{N}_{20} \mathrm{P}_{15} \mathrm{~K}_{30} \mathrm{~S}_{10} \mathrm{Zn}_{3} \mathrm{~B}_{1.5} \mathrm{~kg} \mathrm{ha}^{-1}\right), \mathrm{T}_{2}=$ IPNS (Inorganic) $+2.5 \mathrm{t} \mathrm{ha}^{-1}$ cowdung, $\mathrm{T}_{3}=$ IPNS (Inorganic) $+5 \mathrm{t} \mathrm{ha}^{-1}$ cowdung, $\mathrm{T}_{4}=$ IPNS (Inorganic) $+1.5 \mathrm{t} \mathrm{ha}^{-1}$ poultry manure, $\mathrm{T}_{5}=$ IPNS (Inorganic) $+3 \mathrm{t} \mathrm{ha}^{-1}$ poultry manure and $\mathrm{T}_{6}=$ Control. The results reveal that the integrated nutrient management had significant effects on the plant height, number of branches per plant, number of pods per plant, number of seeds per pod, 1000-seed weight, and seed yield of lentil. The maximum seed yield $\left(1216 \mathrm{~kg} \mathrm{ha}^{-1}\right)$ as well as protein content $(26.1 \%)$ were recorded with $\mathrm{T}_{4}$ treatment. The results advocate that satisfying the recommended dose through application of poultry manure @ $1.5 \mathrm{t} \mathrm{ha}^{-1}$ with IPNS inorganic fertlizer could be suggested for achieving yield miximization of lentil in chhiata soil series of Gazipur.
\end{abstract}

Keywords: Integrated nutrient management, yield attribute, quality, lentil yield

\section{Introduction}

Lentil (Lens culinaris Medik) is an important food legume with various uses as food because of its protein-rich grains. Lentil is the second most important pulse crop of Bangladesh in terms of area (2.704 lakh hectares) and production (3.555 lakh metric ton) (BBS, 2016) and it ranks the highest in terms of consumer preference as total pulse consumption (Krishi Diary, 2018). Lentil is also important in crop diversification in the cropping systems of Bangladesh. Lentil productivity is below potential due to low input usage and limited usage of modern agronomic practices. Declining soil fertility is major constraints to crop production. Organic manures facilitate improve most of the physical, biological and chemical characteristics of soil, thus improving soil fertility (Vishnoi et al.,

${ }^{1}$ Scientific Officer, Pulse Research Sub-station, Bangladesh Agricultural Research Institute (BARI), Gazipur, ${ }^{2}$ Senior Scientific Officer, Soil and Water Management Section, HRC, BARI, Gazipur, ${ }^{3}$ Chief Scientific Officer, Soil Science Division, BARI, Gazipur, ${ }^{4}$ Senior Scientific Officer, TCRC, BARI, Gazipur, ${ }^{5}$ Ex-Agricultural Development Officer, IRRI-Bangladesh. 
2013; Zeidan, 2007). Nutrients play an important role for increasing the yield of lentil through their effect on the plant itself and on the nitrogen fixing by symbiotic process (Sahu et al., 2017). However, balanced fertilization including manures can increase the yield of lentil. Conjunctive use of manure along with chemical fertilizers reduces organic carbon depletions and the gap between potential yield and actual yield is bridged to a large extent (Tolanur and Badanur, 2003). Cowdung and poultry manure are the two common sources of organic manure. Between them, poultry manure is a rich source of nutrients as it contains 3.03 percent of nitrogen, 2.63 percent of phosphorus and 1.4 percent potassium (Vishnoi et al., 2013). Hence, attention is needed to increase organic matter content in soil through balanced fertilization accompanied with organic manure. Therefore, the experiment was undertaken to evaluate the proper organic source and to determine the optimum dose of organic and inorganic sources of nutrients for achieving higher yield of lentil.

\section{Materials and Methods}

The field experiment was conducted at research field of Pulse Research substation, Bangladesh Agricultural Research Institute (BARI), Gazipur during rabi seasons of 2015-16 ( $1^{\text {st }}$ year) and 2016-17 ( $2^{\text {nd }}$ year). The land of Gazipur is medium high with fine-textured (clay loam) grey terrace soils. It belongs to Chhiata soil series under the agroecological zone - Madhupur Tract (AEZ-28). The experimental area received rainfall from 1.40 to $118 \mathrm{~mm}$ during October to March. The mean minimum and maximum air temperatures during October to March of the experiment were $21.4 \& 28.6^{\circ} \mathrm{C}$ in the $1^{\text {st }}$ year and $20.3 \& 29.0^{\circ} \mathrm{C}$, respectively in the $2^{\text {nd }}$ year. The average minimum and maximum humidity (\%) were 51 and 88 during October to March. The initial soil $(0-15 \mathrm{~cm})$ sample and all manure samples were analyzed as outlined by Page et al. (1982). Cowdung and poultry manure that used in the experiment were analysed by the standard methods. The results of chemical analysis are shown in Tables 1 and 2.

The land was prepared by a tractor operated chisel plough and then rotavator was used for breaking the clod and finaly the land was leveled by the leveler. The experiment was planned with six treatments such as $\mathrm{T}_{1}=$ Recommended dose $\left(\mathrm{N}_{20} \mathrm{P}_{15} \mathrm{~K}_{30} \mathrm{~S}_{10} \mathrm{Zn}_{3} \mathrm{~B}_{1.5} \mathrm{~kg} \mathrm{ha}^{-1}\right)$ as per FRG, (2012), $\mathrm{T}_{2}=$ IPNS (Inorganic) $+2.5 \mathrm{t}$ ha${ }^{1}$ cowdung, $\mathrm{T}_{3}=$ IPNS (Inorganic) $+5 \mathrm{t} \mathrm{ha}^{-1}$ cowdung, $\mathrm{T}_{4}=$ IPNS (Inorganic) $+1.5 \mathrm{t}$ $\mathrm{ha}^{-1}$ poultry manure, $\mathrm{T}_{5}=$ IPNS (Inorganic) $+3 \mathrm{t} \mathrm{ha}^{-1}$ poultry manure and $\mathrm{T}_{6}=$ Control (no addition of fertilizer or manure). The treatments of the experiment were laid out in randomized complete block design (RCBD) with three replications. The unit plot size was $12 \mathrm{~m}^{2}(4 \mathrm{~m} \times 3 \mathrm{~m})$. Nutrients $\mathrm{N}, \mathrm{P}, \mathrm{K}, \mathrm{S}, \mathrm{Zn}$ and B were applied as urea, TSP, MoP, gypsum, zinc sulphate (heptahydrate) and boric acid; respectively during final land preparation.The test crop variety was BARI Masur-7. Seeds were sown in the $3^{\text {rd }}$ week of November in both years at a rate of $35 \mathrm{~kg} \mathrm{ha}^{-1}$, sowing was done continuously in rows at a depth of $2-3 \mathrm{~cm}$ maintaining row to row spacing of $30 \mathrm{~cm}$. The seeds were treated using the fungicide Provex 200 (at 


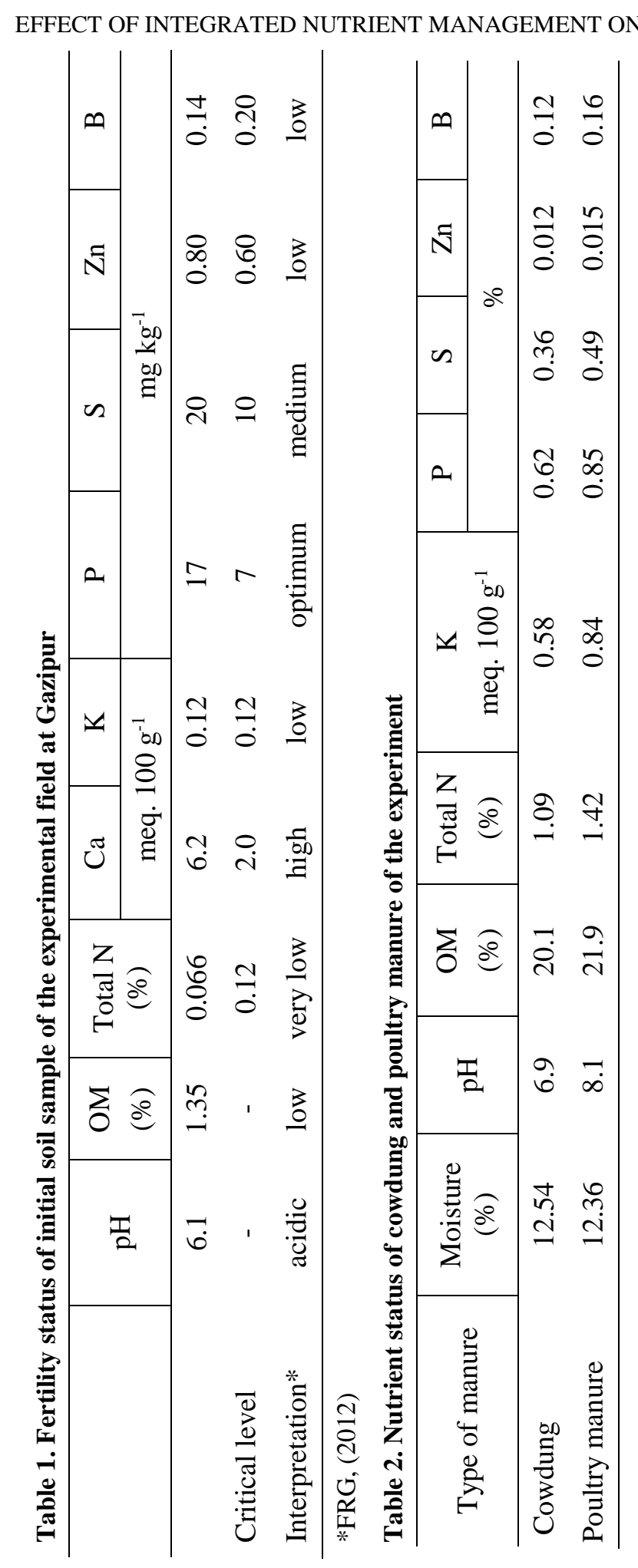


$2.5 \mathrm{~g} \mathrm{~kg}^{-1}$ seeds) before sowing for controlling of root rot disease. Hand weeding as well as thining of seedlings was done at 25 days after sowing (DAS). Again, hand weeding was done at around 50 DAS.Two sprays were done with fungicide of Rovral starting from 55 DAS to control Stemphylium blight disease and two times insecticide (Karate @ $2 \mathrm{ml} \mathrm{L}^{-1}$ of water) was sprayed at 10 days interval starting from 60 DAS to overcome insect infestation. The crop was harvested at maturity.

Data on the seed yield $\left(\mathrm{kg} \mathrm{ha}^{-1}\right)$ at around $10 \%$ moisture basis were recorded from the whole plot technique. For straw yield $\left(\mathrm{kg} \mathrm{ha}^{-1}\right)$, mature plants were collected from two $1 \mathrm{~m}^{2}$ quadrates in each plot at harvest time. Harvest index (\%) was determined as a ratio of economic yield to biological yield (Zerihun et al., 2013). The data of yield attributes included plant height, number of branches plant $^{-1}$ and number of pods plant ${ }^{-1}$ were recorded from ten plants selected randomly from each unit plot. Ten pods were detached randomly from ten plants and the number of seeds per pod was counted and averaged. Thousand seed weight $(\mathrm{g})$ was determined by counting of 500 seeds randomly from each plot and weighing through electronic balance and converting it into 1000-seed weight. Five plants from each plot were chosen randomly at seedling, vegetative, flowering and pod formation stages for recording nodulation per plant. Plants were smoothly uprooted and the soil from roots was removed carefully using tap water. Nodules were separated and counted from each plant and averaged. Separated nodules were sliced into two pieces to observe the inside color for determining of nodule activity. The light-pink or red coloured nodules were considered as active.

Seed samples were digested with di-acid mixture $\left(\mathrm{HNO}_{3}-\mathrm{HClO}_{4}\right)(5: 1)$ as described by Piper (1966) for determination of N concentration (Micro-Kjeldahl method). Protein contein in lentil seed was calculated by multiplying $\% \mathrm{~N}$ by a factor 5.30 (FAO, 2018).

All the data of growth, yield attributing characters, number of nodules per plant and yield of lentil were statistically analysed by ANOVA procedure. Then, multiple comparisons were done by LSD at 5\% level (Statistix 10., 1985).

\section{Results and Discussion}

\section{Growth attributes of lentil}

Growth attributes like plant height and number branches per plant were influenced significantly due to imposing different integrated nutrient treatments (Table 3). In the experiment, the tallest plant $(31.2 \mathrm{~cm})$ was found in $\mathrm{T}_{4}$ treatment which was statistically similar with $\mathrm{T}_{1}, \mathrm{~T}_{2}$ and $\mathrm{T}_{3}$ treatments. The most dwarf plant $(27.5 \mathrm{~cm})$ was observed in $\mathrm{T}_{6}$ treatment (control). The plant height increased progressively due to application of cowdung and poultry manure with inorganic fertilizers. Similar observation was noted by Singh et al. (2011). 


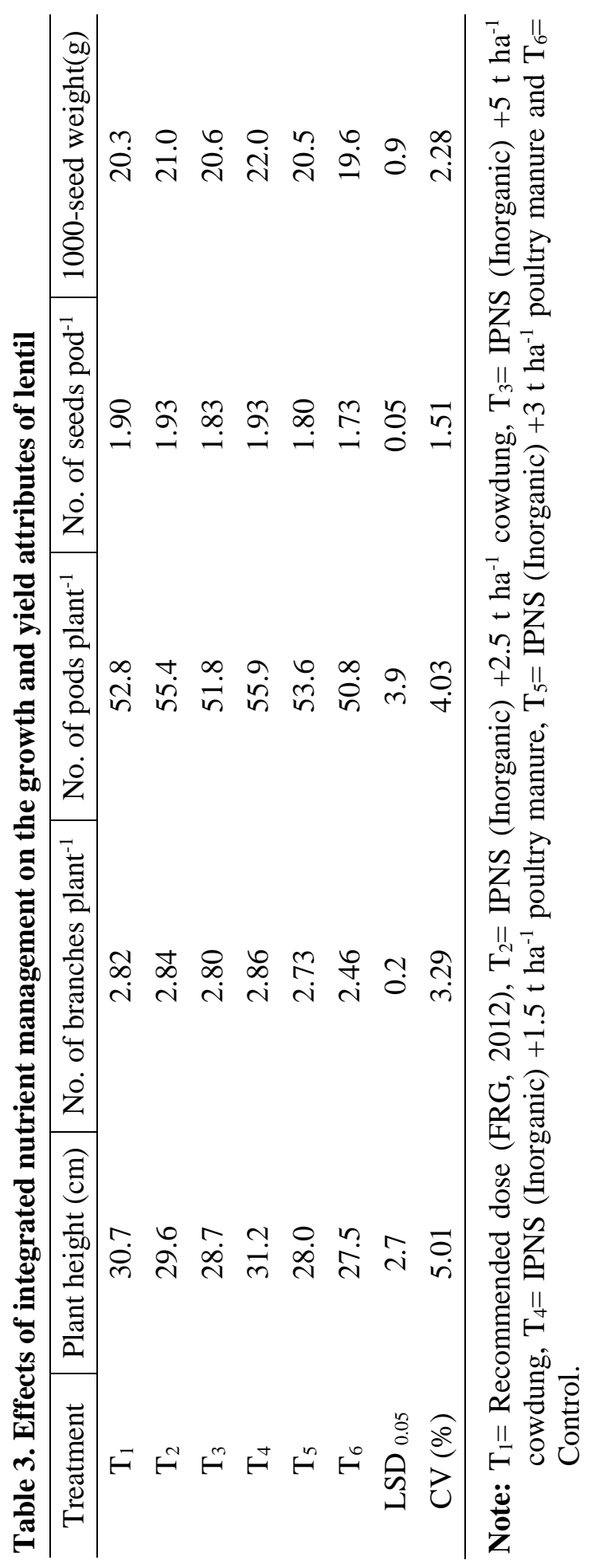




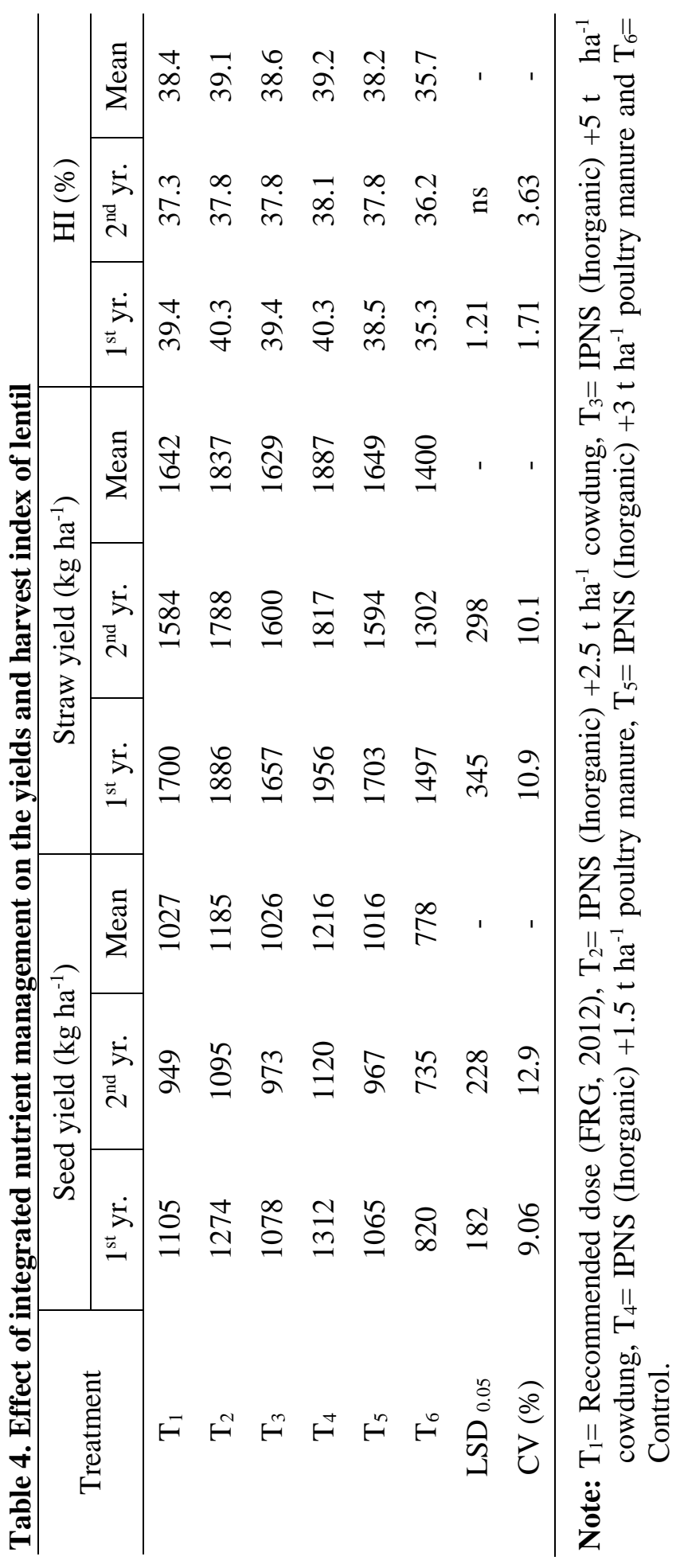


The maximum number of branches per plant (2.86) was recorded from $\mathrm{T}_{4}$ treatment which was statistically similar to $T_{1}, T_{2}, T_{3}$ and $T_{5}$ treatments and the minimum number (2.46) being noted in $\mathrm{T}_{6}$ treatment was significantly inferior to others treatments (Table 3). Application of cowdung or poultry manure along with chemical fertilizers enhanced the branches per plant of lentil. Krishnan (2016) reported the maximum numbers of branches per plant in green gram (11.6 and 12.9) due to application of NPK fertilizers (20:40:20 kg ha-1) with vermicompost and farmyard manure. However, integrated nutrient management is one of the important issues for sustainable crop production.

\section{Yield attributes of lentil}

Significant variation in the number of pods per plant of lentil was observed between the treatments (Table 3). The highest number of pod per plant (55.9) produced in treatment $\mathrm{T}_{4}$ was statistically identical to $\mathrm{T}_{2}(55.4), \mathrm{T}_{5}(53.6)$ and $\mathrm{T}_{1}$ (52.8). The lowest number of pod per plant was recorded in $\mathrm{T}_{6}(50.8)$. Mohammed et al. (2016) observed the possitive effect of poultry litter on the number of pods per plant. This particular parameter is a significant component that directly imparts the effects on potential yield.

The number of seeds per pod also differed significantly among the treatments and the highest was in $\mathrm{T}_{4}$ (1.93) followed by $\mathrm{T}_{2}$ and $\mathrm{T}_{1}$ while the lowest in $\mathrm{T}_{6}(1.73)$. Vishnoi et al. (2013) found that the number of seed per pod was significantly influenced by organic and inorganic sources of phosphorus in lentil. The 1000seed weight ranged from 19.6 to $22 \mathrm{~g}$ and differed significantly among the treatments, the highest weight $(22.0 \mathrm{~g})$ was recorded in $\mathrm{T}_{4}$ and the lowest value (19.6 g) being noted in $T_{6}$ treatment (Table 3). Nandini Devi et al. (2013) noted that seed index of soybean was maximum $(12.86 \mathrm{~g})$ with the integrated application of $75 \%$ RDF coupled with vermicompost at a rate of $1 \mathrm{t} \mathrm{ha}^{-1}$. The above yield attributes was improved due to an adequate supply of nitrogen, phosphorus, potassium and sulphur to the crop at the early stages as well as steady supply of nutrient at later stages for application of manure.

\section{Yield of lentil}

Seed and straw yields were increased due to application of cowdung or poultry manure along with inorganic fertilizers over the control treatment (Table 4). The highest seed yield of lentil was recorded in $\mathrm{T}_{4}\left(1312 \mathrm{~kg} \mathrm{ha}^{-1}\right.$ in the $1^{\text {st }}$ year and $1120 \mathrm{~kg} \mathrm{ha}^{-1}$ in the $2^{\text {nd }}$ year) which was statistically similar to $\mathrm{T}_{2}$ in the $1^{\text {st }}$ year and similar to $\mathrm{T}_{2}, \mathrm{~T}_{3}, \mathrm{~T}_{5}$ and $\mathrm{T}_{1}$ in the $2^{\text {nd }}$ year. The lowest seed yield of lentil $\left(820 \mathrm{~kg} \mathrm{ha}^{-1}\right.$ in the $1^{\text {st }}$ year and $735 \mathrm{~kg} \mathrm{ha}^{-1}$ in the $2^{\text {nd }}$ year $)$ were noted in $\mathrm{T}_{6}$ treatment. The mean seed yield ranged from 778 to $1216 \mathrm{~kg}$ $\mathrm{ha}^{-1}$ across the treatments (Table 4). Singh et al. (2018) reported that grain and straw yield were significantly $(\mathrm{P}<0.05)$ enhanced in balanced (with 
FYM) fertilization treatments compared with the unfertilized control. Organic manure (poultry manure) with mineral fertilizer might had long residual effect which enhances the growth and yield of the crop. However, it is reported in this study that poultry manure contained high percentage of nitrogen, phosphorus, potassium and other nutrients which ultimately improved the crop productivity. Ewulo (2005) corroborated the similar result that poultry manure contained higher amount of nitrogen and phosphorus for the healthy growth of plants. Significantly the highest straw yield was produced in $\mathrm{T}_{4}\left(1956 \mathrm{~kg} \mathrm{ha}^{-1}\right.$ in the $1^{\text {st }}$ year and $1817 \mathrm{~kg} \mathrm{ha}^{-1}$ in the $2^{\text {nd }}$ year $)$ which was statistically alike with $\mathrm{T}_{5}, \mathrm{~T}_{3}, \mathrm{~T}_{2}$ and $\mathrm{T}_{1}$ treatments and the lowest in $\mathrm{T}_{6}\left(1497 \mathrm{~kg} \mathrm{ha}^{-1}\right.$ in the $1^{\text {st }}$ year and $1302 \mathrm{~kg} \mathrm{ha}^{-1}$ in the $2^{\text {nd }}$ year). The mean straw yield of lentil (average of two years) varied from 1400 to $1887 \mathrm{~kg} \mathrm{ha}^{-1}$ across the treatments (Table 4). The harvest index (HI) varied between 35.3$40.3 \%$ in the $1^{\text {st }}$ year and $36.2-38.1 \%$ in the $2^{\text {nd }}$ year across the the treatments. However, the highest harvest index $\left(40.3 \%\right.$ in the $1^{\text {st }}$ year and $38.1 \%$ in the $2^{\text {nd }}$ year) was recorded in $\mathrm{T}_{4}$ treatment and the lowest in $\mathrm{T}_{6}$ treatment in both years. Krishnan (2016) noted that maximum harvest index of green gram (29.5\%) was recorded under NPK (20:40:20 kg per hectare) with farmyard manure.

Table 5. Effect of integrated nutrient management on the number of nodules per plant in different dates (pooled data of 2- years)

\begin{tabular}{ccccc}
\hline Treatment & $\begin{array}{c}\text { No. of nodules } \\
\text { plant }^{-1} \text { after 30 } \\
\text { DAS }\end{array}$ & $\begin{array}{c}\text { No. of nodules } \\
\text { plant }^{-1} \text { after 45 } \\
\text { DAS }\end{array}$ & $\begin{array}{c}\text { No. of nodules } \\
\text { plant }^{-1} \text { after 60 } \\
\text { DAS }\end{array}$ & $\begin{array}{c}\text { No. of nodules } \\
\text { plant }^{-1} \text { after 75 } \\
\text { DAS }\end{array}$ \\
\hline $\mathrm{T}_{1}$ & 8.2 & 18.4 & 24.5 & 21.1 \\
$\mathrm{~T}_{2}$ & 10.5 & 21.3 & 30.8 & 23.5 \\
$\mathrm{~T}_{3}$ & 9.0 & 22.0 & 32.0 & 28.9 \\
$\mathrm{~T}_{4}$ & 12.7 & 26.6 & 35.1 & 30.0 \\
$\mathrm{~T}_{5}$ & 10.0 & 23.2 & 32.6 & 28.7 \\
$\mathrm{~T}_{6}$ & 8.0 & 16.9 & 23.8 & 22.8 \\
$\operatorname{LSD}(0.05)$ & 2.7 & 3.5 & 2.7 & 3.5 \\
$\mathrm{CV}(\%)$ & 15.0 & 8.93 & 4.97 & 7.48 \\
\hline
\end{tabular}

Note: $T_{1}=$ Recommended dose (FRG, 2012), $\mathrm{T}_{2}=$ IPNS (Inorganic) $+2.5 \mathrm{tha}^{-1}$ cowdung, $\mathrm{T}_{3}=$ IPNS (Inorganic) $+5 \mathrm{tha}^{-1}$ cowdung, $\mathrm{T}_{4}=$ IPNS (Inorganic) $+1.5 \mathrm{t} \mathrm{ha}^{-1}$ poultry manure, $\mathrm{T}_{5}=$ IPNS (Inorganic) $+3 \mathrm{tha}^{-1}$ poultry manure and $\mathrm{T}_{6}=$ Control. 


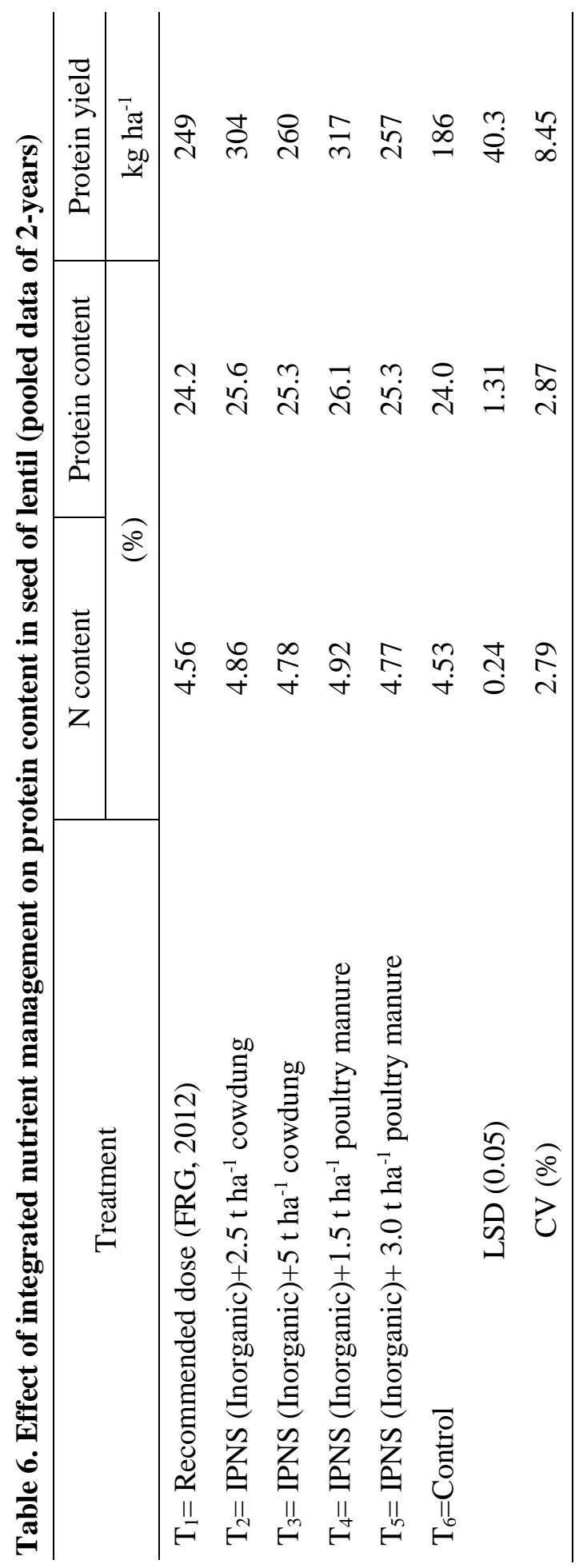




\section{Nodulation of Lentil}

The number of nodules per plant was influenced significantly by the different treatments. Per plant nodules in each treatment progressively increased from 30 days after sowing (DAS) to 60 DAS, and then decreased in irrespective of treatments (Table 5). Per plant nodules ranged across the treatments from 4.012.7 at 30 DAS; $16.9-26.6$ at 45 DAS; $23.8-35.1$ at 60 DAS and 22.8-30.0 at 75 DAS. The highest number of nodules $(12.7,26.6,35.1$ and 30.0 , respectively) was always recorded in $\mathrm{T}_{4}$ treatment and the lowest number of nodules noted in $\mathrm{T}_{6}$ (control) treatment (Table 5). Nandini Devi et al. (2013) reported that the maximum nodules per plant of soybean (43.00) were found in the integration of $75 \%$ RDF with organic vermicompost at a rate of $1 \mathrm{t} \mathrm{ha}^{-1}$. It reveals that the minimum numbers of nodules per plant were formed at the earlier stage (30 DAS) of the crop which gradually increased with time and reached the maximum value at the mid-flowering stage (60 DAS) and then declined to the reduced number of nodules after completion of flowering of the crop. This finding was supported by Kevin Zaychuk (2006). Albiach et al. (2000) noted that organic fertilizers are not only the source of organic matter and nutrient, but also boost microbial population and improve physical, biological and chemical properties of the soil. Thus, with long-term retention of organic matter in agricultural systems, survival and growth condition of rhizobia may improve with time and allow nodulation without the addition of lime.

\section{Protein content of lentil}

The $\mathrm{N}$ content as well as protein content of lentil seed were significantly influenced by integrated nutrient management. In the experiment, the highest protein content $(26.1 \%)$ was achieved in $\mathrm{T}_{4}$ treatment that was statistically identical with $\mathrm{T}_{2}, \mathrm{~T}_{3}$ and $\mathrm{T}_{5}$ treatments and lowest protein content $(24.0 \%)$ was recorded in control $\left(\mathrm{T}_{6}\right)$ treatment (Table 6). Among various treatments, the treatment $\mathrm{T}_{4}$ \{IPNS (Inorganic)+1.5 $\mathrm{t} \mathrm{ha}^{-1}$ poultry manure\} produced significantly higher protein yield $\left(317 \mathrm{~kg} \mathrm{ha}^{-1}\right)$ in lentil seed (Table 6). Nandini Devi et al. (2013) reported that integration of $75 \%$ RDF with vermicompost at the rate of $1.0 \mathrm{t} \mathrm{ha}^{-1}$ produced significantly higher protein content of soybean seed.

\section{Conclusion}

From the two years study, the lentil performed better in $\mathrm{T}_{4}$ \{IPNS (Inorganic) $+1.5 \mathrm{t} \mathrm{ha}^{-1}$ poultry manure $\}$ treatment regarding to plant height, branches per plant, pod number, seed weight, nodule formation and protein yield. The highest seed yield was produced from the treatment of IPNS (Inorganic) $+1.5 \mathrm{t} \mathrm{ha}^{-1}$ poultry manure $\left(\mathrm{T}_{4}\right)$. The results suggest that satisfying the recommended fertilizer dose through application of poultry manure@1.5 $\mathrm{t} \mathrm{ha}^{-1}$ with IPNS 
inorganic fertlizer could be suggested for achieving the maximum yield potential of lentil at chiata series soil of Gazipur.

\section{References}

Albiach, R., R. Canet, F. Pomares, and F. Ingelmo. 2000. Microbial biomass content and enzymatic activities after the application of organic amendments to a horticultural soil. Biores. Technol., 75: 43-48.

BBS. 2016. Yearbook of Agricultural Statistics of Bangladesh-2015. Bangladesh Bureau of statistics. Statistics and informatics Division. Ministry of planning. Government of the people's republic of Bangladesh. Dhaka.p. 138.

Ewulo, B.S. 2005. Effect of poultry dung and cattle manure on chemical properties of clay and sandy clay loam soil. J. Anim. Vet. Adv., 4 (10):839-841.

FAO. 2018. Analysis of Protein. Food and agriculture Origination publication, FAO Food and Nutrition Paper 14/7, Centre for Food Safety, UN.

http://www.cfs.gov.hk/english/programme/programme_nifl/files/Analysis_of_Protei n.pdf (accessed on 08 January 2018)

FRG (Fertilizer Recommendation Guide). 2012. Fertilizer Recommendation Guide, Published by Bangladesh Agricultural Research Council, Dhaka, Bangladesh.

Kevin Zaychuk., 2006. Nodulation and Nitrogen Fixation Field Guide for the Assessment of Pulse Crops. Edited by Kevin Zaychuk, 20/20 Seed Labs Inc-December, 2006. http://www.agr.gov.sk.ca/docs/production/inoculationpulses.asp

Krishi dairy. 2018. Krishi Tatha Services, Department of Agriculture Extension (DAE), Khamarbari, Dhaka. Bangladesh. 15p.

Krishnan, T.K. 2016. Effect of inorganic and organic fertilizer on growth and yeild of green gram (Vigna radiata L. Wilezek) under guava based agri-horti system. MS Thesis, Department of Agronomy, Institute of Agricultural Sciences, Banaras Hindu University, Varanasi (up)-221005, India

Mohammed, H., M. Shamim, A. Sultan, M. Abuyusuf, and B. Purnendu. 2016. Effect of biochar, poultry litter, cowdung and vermicompost on the yield of lentil. Biodiversity management of organic farming enhances agricultural ssustainability. https://www.researchgate. Net/publication/ 275270245.

Nandini Devi K., T.B. Singh, H.S. Athokpam, N.B. Singh and D. Shamurailatpam. 2013. Influence of inorganic, biological and organic manures on nodulation and yield of soybean (Glycine max Merril L.) and soil properties. Autralian Journal of Crop Science, 7(9):1407-1415.

Page, A.L., R.H. Miller, and D.R. Keeney (Eds.). 1982. Agronomy Series 9 ASA, SSSA. Methods of Soil Analysis (Part 2, 2nd ed., pp. 403-427). Am. Soc. Agron., Madison, USA.

Piper, C.S. 1966. Soil and Plant Analysis. Adelaide University Press, Australia

Sahu, G., Chatterjee N. and Ghosh G. K. 2017. Integrated nutrient management in lentil (Lens culinaris Medikus) in red and lateritic soils of West Bengal. Bull. Env. Pharmacol.life Sci., 6 (4): 55-62. 
Singh, G. H., H.S. Ram, N. Sekhon, Aggarwal and V. Khanna. 2011. Effect of nutrient management on nodulation, growth and yields of Lenlil (Lens culinaris Medik.) genotypes. American-European Journal of Agronomy. 4(3):46-49.

Singh, S.R., D.K. Kundu, P. Dey, P. Singh, B.S. Mahapatra. 2018. Effect of balanced fertilizers on soil quality and lentil yield in Gangetic alluvial soils of India. The
Journal
of Agricultural
Science,
156 ,
225-240. https://doi.org/10.1017/S0021859618000254

Statistix 10. 1985. An Analytical Software, Po Box 12185, Tallahassee, FL 32317, Copy right (C) 1985-2013

Tolanur, S.T. and V.P. Badanur. 2003. Effect of integrated use of organic manure, green manure and fertilizer nitrogen on sustaining productivity of Rabi sorghum-chickpea system and fertility of a vertisol. J. Indian Soc. Soil Sci., 51:41-44.

Vishnoi, G., J.S. Kumar, J.S.A. and P.J. George. 2013. Effect of organic manure and phospjorus fertilizers on growth, yield and economics of lentil in sandy loam soil. An Asian Journal of Soil Science, 8(1): 76-79.

Zeidan, M.S. 2007. Effect of organic manure and phosphorus fertilizers on growth, yield and quality of lentil plants in sandy soil. Res. J Agric. Biol. Sci., 3(6):748-752.

Zerihun, A., J. J. Sharma, D. Nigussie and K. Fred. 2013. The effect of integrated organic and inorganic fertilizer rates on performances of soybean and maize component crops of a soybean/maize mixture at Bako, Western Ethiopia. Afr. J. Agric. Res., 8(29), pp. 3921-3929, DOI: 10.5897/AJAR12.1044 